Recenzje 



\title{
PODNIEŚĆ NA SIEBIE PISZĄCĄ RĘKĘ
}

\author{
Stefan Chwin, Samobójstwo jako przygoda wyobraźni, \\ wyd. 2, Wydawnictwo Tytuł, Gdańsk 2011.
}

Książka Stefana Chwina już od pierwszych swych stron obiecuje bardzo wiele. Jednak czy może być inaczej, jeśli podstawowy jej temat, samobójstwo, nie tylko nie został pozbawiony, podejrzanej skądinąd, mocy fascynowania przez ogrom literatury na jego temat (jej znajomość i umiejętność wykorzystania to niewątpliwy walor książki), ale i w historii dyskursów o nim - nawet, a może zwłaszcza jeśli ograniczyć się wyłącznie do „humanistycznych" ujęć - odnaleźć można tak ważkie pozycje, jak chociażby Mit Syzyfa Alberta Camusa („Jest tylko jeden problem prawdziwie poważny: samobójstwo"1ㄱ), Podnieść na siebie rękę Jeana Améry’ego czy Bóg bestia Ala Alvareza? Zabieranie głosu à propos musi więc być $\mathrm{w}$ tym wypadku bardziej niż uzasadnione. I, w przypadku recenzowanej pozycji, z pewnością jest, a to z co najmniej trzech przyczyn.

Po pierwsze, autor deklaruje, że temat ów interesuje go od dawna, czego dowody odnaleźć można na obu podstawowych polach działalności twórczej Chwina: w pisaniu literatury i pisaniu o literaturze. Tym samym studium Samobójstwo jako przygoda wyobraźni nabiera charakteru podsumowania wieloletnich refleksji.

Po drugie, Chwin lokuje swe rozważania na polu wciąż stosunkowo mało obleganym, a z pewnością intrygującym: nie egzystencjalny wymiar samobójstwa („psychologia motywów”), nie etiologia będzie go interesować, lecz

\footnotetext{
1 A. Camus, Mit Syzyfa, [w:] tenże, Dwa eseje, przeł. J. Guze, Wydawnictwo Krąg, Warszawa 1991, s. 11.
} 
„poetyka” samego czynu. Założenia są tu pokrewne z poetyką opisową właśnie. Ta ostatnia zakłada, że użycie każdego środka wyrazu jest konsekwencją wyboru jednej z szeregu dostępnych możliwości. Już sam ów wybór analizować można jako gest pozytywny (wybieram to dlatego, że...), jak i negatywny (odrzucam inne opcje, gdyż...). To, co zostaje wybrane zaś, przynosi nie tylko określony efekt, ale i wnosi wraz z sobą pewne pole konotacji i "pamięć" o wcześniejszych użyciach. Tak jak zasadą każdego tekstu jest jego intertekstualność, tak i każdego samobójstwa - „intersamobójczość”. Analizie poddane zostają więc: przygotowanie, wybór metody (przestrzeń, rekwizyty, czas umierania) i sposób realizacji (a także kulturowe „ikony”, które temu towarzyszą, swoiste samobójcze toposy czy archetypy), tworzenie „symbolicznej kartografii ciała", umożliwiającej tegoż ciała uśmiercenie, stopniowe wkraczanie w fantazmatyczną przestrzeń uprzednio przygotowanej sceny ostatecznego gestu (tytułowe „doświadczenie wyobraźni”). Chwin rekonstruuje też specyficzne "centralne metafory istnienia”, które podbudowują decyzję o samobójstwie, wreszcie zaś odnosi się do tajemniczej relacji samobójcy z językiem, pismem, słowem (jednym z elementów samobójczego „rytuału” jest wszak zostawienie, bądź nie, listu), starając się odpowiedzieć na pytanie: „Jak wyobraźnia samobójcy pracuje w słowie, by śmierć uczynić możliwą"??2.

Na marginesie dodam, że tym samym autor dystansuje się od kwestii natury etycznej. Ani samobójców nie będzie gloryfikował, ani ich potępiał, potencjalnych samobójców zaś (a więc - zgodnie z tezą książki - każdego jej czytelnika) ani ku targnięciu się na swe życie popychał, ani od tego odwodził. Samobójstwo stanowi dla niego tylko i wyłącznie przedmiot opisu i to opisu zagęszczonego, operującego przede wszystkim na polach estetyki, "poetyki marzenia” (Gaston Bachelard) czy „krytyki archetypicznej” (Northrop Frye). (Dodam, że autor nie zawsze pozostaje konsekwentny, zdarza mu się bowiem, na przykład, krytykować pewne „terapeutyczne” założenia suicydologii).

Po trzecie wreszcie, asumptem do napisania studium o samobójstwie było szokujące $\mathrm{w}$ swej niezrozumiałości zdarzenie z życia samego autora. Jeden z jego znajomych, człowiek radosny, dowcipny, z pasjami, odnoszący sukcesy, powiedział mu któregoś dnia, że „zabić się to nic takiego”. Parę lat później zaś - nikomu nic nie tłumacząc i nie pozostawiając żadnych śladów, które pozwoliłyby domniemywać jakąkolwiek przyczynę - popełnił samobójstwo. „Literatura, sztuka i psychologia kochają efektowną pornografię samobójstwa” - pisze Chwin, a być może jest tak, że "zabić się to tyle co wyjść z domu po papierosy" (s. 11). Nie mogąc się pogodzić z druzgoczącym faktem ostatecznego niezrozumienia (tego człowieka już nie ma, nie ma nawet śladów, które mogłyby, w enigmatycznym języku śladów, coś wyjaśnić), Chwin pi-

2 S. Chwin, Samobójstwo jako przygoda wyobraźni, wyd. 2,Wydawnictwo Tytuł, Gdańsk 2011, s. 343. Dalsze odnośniki do tej pozycji lokalizuję w tekście. 
sze swą książkę. Być może zdeponowana na przestrzeni dziejów w dziełach sztuki kulturowa wiedza o samobójstwie pozwoli mu choć trochę rozjaśnić dręczący mrok, jaki pozostawił za sobą ów mężczyzna poprzez swe słowo i gest.

Stefan Chwin, człowiek, objawia się klamrowo w najkrótszych dwóch pierwszych i ostatnim rozdziale. Pomiędzy nimi zaś, przez czterysta stron, odzywa się Chwin-badacz, Chwin-profesor, któremu niejako Chwin-człowiek zlecił karkołomne, detektywistyczne śledzenie „obrotów samobójczej wyobraźni” (s. 13). Zanim omówię krytycznie „naukową" część Samobójstwa jako doświadczenia wyobraźni, odniosę się do zagubienia wobec pewnych paradoksów $w^{3}$, które eksplicytnie formułuje rozmiarowo niewielka, lecz jeśli chodzi o ogólny wydźwięk - być może nawet istotniejsza partia "osobista”.

Znajomy Chwina, autor owego niepokojącego sformułowania „nic takiego" (przypomina się „nic to” Wołodyjowskiego), przedstawiony jest jednocześnie jako ktoś skrajnie obcy, niepojęty, jak i jako sytuacyjna (bądź nie) możliwość życiowa każdego człowieka. Perspektywa samobójcy - „szczególnego rodzaju wtajemniczenie w kondycję ludzką" (s. 5), wyswobodzenie się ze "społecznej tresury" (s. 12), narzucającej imperatyw życia chociażby jedynie pod postacią eskalowania strachu przed śmiercią - jest w punkcie wyjścia zarówno autorowi, jak i z założenia podzielającemu jego racjonalność czytelnikowi zasadniczo obca ${ }^{4}$. Obcość ta jest jednak ukazana jako coś przekraczalnego, a właściwie - odwracalnego (nie w sensie przywrócenia wcześniejszego stanu rzeczy, lecz odwrócenia "o sto osiemdziesiąt stopni”). Przyjęcie owej "odwrotnej perspektywy” przedstawiane jest z kolei raz jako coś zupełnie nieumotywowanego, samorzutnego, zwyczajnego niczym wypicie szklanki mleka (jakby nagle oczywistym stawało się to, co chwilę wcześniej było nie do pomyślenia), raz zaś jako konsekwencja szczególnych okoliczności czy doświadczeń: „Im dłużej zajmuję się tą sprawą, tym większej nabieram pewności, że istnieją sytuacje, w których samobójstwo popełniłby każdy. Jeśli nie popełniamy go, to tylko dlatego, że jeszcze nie znaleźliśmy się w takiej sytuacji" (s. 412).

Spróbujmy to uprościć. Samobójca jest kimś szczególnym, ale i kimś zwyczajnym w szczególnych okolicznościach. Każdy może przyjąć, czy raczej

${ }^{3}$ Rzecz to $w$ przypadku samobójstwa wręcz obowiązkowa, weźmy pierwsze z brzegu: samobójstwo to tchórzostwo wymagające wielkiej odwagi; samobójstwo jest pewnym rodzajem "ślepoty" na łaskawość świata lub wręcz przeciwnie - wyzbyciem się złudzeń co do jego natury.

${ }^{4}$ Na myśl przychodzi mi tu Jean Améry, który przedstawiał samobójcę - widzianego z perspektywy jego otoczenia - jako „ostatniego wielkiego outsidera”. Jego akt bowiem „jest dla społeczeństwa bardziej negatywny niż zachowanie homoseksualne: to ostatnie odrzuca tylko logikę prokreacji, nie istnienia”. Dodajmy, że Améry pisał te słowa już z „odwrotnej perspektywy". Zob. J. Améry, Podnieść na siebie rękę. Dyskurs o dobrowolnej śmierci, [w:] tenże, O starzeniu się. Podnieść na siebie rękę, przeł. B. Baran, Czytelnik, Warszawa 2007, s. 179. 
„nabawić się" tej „odwrotnej perspektywy”, która samobójstwo umożliwia. Może, ale nie musi. Może „nabawić się” jej z pewnych przyczyn, albo i z żadnych. Wartość poznawcza tego typu stwierdzeń jest oczywiście niewielka. Co nie zmienia faktu, że bronią się one z zupełnie innych powodów. Analogię odnajduję co prawda daleką, ale - jak sądzę - wiele wyjaśniającą. Roland Barthes, analizując teksty o modzie, wskazywał na częstą obecność tzw. pustych, redundantnych stwierdzeń (np. „suknie z rękawami albo bez”) ${ }^{5}$. Oczywistym jest, że wszystkie suknie albo mają rękawy, albo ich nie mają, zdanie to niczego więc nie komunikuje, ale nie na tym wszak polega jego funkcja. Fakt, że coś (rękawy w tekście o modzie, samobójstwo u Chwina) uznaje się za na tyle ważne, by wypowiedzieć nawet takie zdanie, które nic o tym nie mówi, związane jest ze szczególnym zwróceniem uwagi na owe coś (funkcja deiktyczna), specyficznego rodzaju emfazą. Tak też i Chwin (a dodajmy, gwoli sprawiedliwości, że w przeciwieństwie do przykładu Barthes'a, każde z jego stwierdzeń samo w sobie jest stwierdzeniem „mocnym”) nadaje w ten sposób przedmiotowi swych rozważań istotność.

Poza rozwlekłymi (lecz rzadko kiedy nużącymi) partiami analiz i interpretacji dzieł literackich i malarskich, można wyodrębnić w studium Chwina dwie podstawowe tezy. Pierwsza mówi, że w literaturze polskiej dominuje (od czasów romantyzmu, wcześniej wszak samobójstwo jako temat literatury właściwie nie istniało) motyw samobójstwa altruistycznego, zaś marginalizowane jest tzw. samobójstwo egzystencjalne (sam autor przyznaje, że w twórczości swej dysproporcję tę próbuje zmniejszyć). Samobójstwo altruistyczne (określenie Emile'a Durkheima) to takie, które ma na celu poprawę warunków życia wspólnoty (narodu), z której wywodzi się samobójca. Podstawą tego typu samobójstwa jest silna integracja ze wspólnotą, celem zaś - poświęcenie się dla jej dobra. Ma więc ono charakter polityczny i może przybrać wymiar, w pewnym sensie, "militarny” (wymierzony przeciw wrogom owej wspólnoty). By ukazać historię tego typu gestów, autor sięga aż do Biblii, wskazując na ambiwalencję postępowania Samsona, który wszak zabija się (powinien być więc potępiony), a mimo to przedstawiany jest raczej jako wzór do naśladowania (oczywiście, w określonych okolicznościach). Dalej legenda o Wandzie, która rzuciła się do Wisły, bo Niemca nie chciała, a za nią cały korowód literackich postaci - Konrad Wallenrod, Lilla Weneda, hrabia Henryk, Ordon, Michał Wołodyjowski, na końcu zaś okrutna demistyfikacja tego typu gestu w Matej Apokalipsie Tadeusza Konwickiego. (Oczywiście nie jest to "fenomen" typowo polski, o czym świadczą nie tylko antropologiczne przykłady przedstawione w klasycznym studium Durkheima, ale i takie zjawiska jak działania pilotów-kamikadze, terrorystów islamskich czy wreszcie

\footnotetext{
${ }^{5}$ Zob. R. Barthes, System mody, przeł. M. Falski, Wydawnictwo UJ, Kraków 2005.
} 
samospalenia buddyjskich mnichów). Samobójstwa egzystencjalne zaś to samobójstwa „bez materialnych, widzialnych zewnętrznych powodów, wynikające nie tyle z konkretnych, jednostkowych, życiowych kłopotów samobójcy, ile z całościowego negatywnego osądu reguł ludzkiej egzystencji” (s. 241). Wynikają one ze „szczególnej aury spowijającej światoodczucie [samobójcy - przyp. P.J.], szczególnej inności spojrzenia na rzeczywistość (...), odmienności całościowego doznania egzystencji” (s. 215).

To właśnie samobójstwa egzystencjalne oraz metafory egzystencji, które leżą u ich podstaw, najbardziej Chwina zajmują. Jednakowoż tego typu opozycyjne ustawienie problemu (dekonstruowane przez sam tekst mówiący o „konkretnych, jednostkowych, życiowych” kłopotach samobójcy), nie tylko znacznie zawęża pole patrzenia (gdzie bowiem samobójstwa z miłości, gdzie samobójstwa z rozpaczy?), ale i - aplikowane do badania tekstów kultury ukazuje swoją sztuczność i schematyczność. Spośród wielu „centralnych metafor istnienia”, które warunkować mają samobójstwo egzystencjalne, jedna zaledwie (życie jako „grzech istnienia”) odnajduje literackie spełnienie pod postacią samobójstwa właśnie (doskonałe rozważania o śmierci Kiriłłowa z Biesów Fiodora Dostojewskiego), jedna - „matnia” Witkacego - owocuje samobójstwem autora (choć, jak dobrze wiadomo, w grę wchodziły tu też zewnętrzne, polityczne par excellence przyczyny), w pozostałych zaś przypadkach („mdłości” Jean-Paula Sartre’a, życie jako "proces medyczno-sądowy” u Franza Kafki, „matnia” Witolda Gombrowicza) samobójstwo pojawia się, w najlepszym razie, jako temat rozważań (zawartych w samych dziełach, ale też listach czy dziennikach autorów), kiedy indziej zaś - jako efekt pracy interpretacji.

Może taki z tego wniosek płynie - literatura, która snuje refleksję wokół samobójstwa jako jedynej konsekwencji prawdziwego wglądu w naturę świata i życia, rzadko kiedy samobójstwo jako takie przedstawia. I odwrotnie - jeśli w danym dziele samobójstwo istnieje jako motyw, przeważnie nie towarzyszy temu rozbudowana czy wyrazista na jego temat refleksja. Faktem jest, że podczas gdy Chwin poświęca dziesiątki stron rekapitulacji „okołosamobójczych", filozoficznych przeważnie rozważań, odłogiem leży szereg dzieł, których bohaterowie rzeczywiście się zabijają. Czasami jedynie o nich napomina (jak np. w przypadku Wokulskiego z Lalki Bolesława Prusa), inne zaś nie doczekują nawet tego (Werter, Pani Bovary, Anna Karenina, Zenon Ziembiewicz i inni). Chwin zdaje się też zapominać o tych bohaterach romantycznej literatury polskiej, którzy mimo iż dobro narodu za priorytet sobie stawiali, zabijają się lub próbują się zabić „z miłości” (Gustaw z Dziadów czy Kordian). Czyżby wiec teza rzeczywiście była „zbyt ciasna”?

Zarzut „niedoczytania” łatwo jednak daje się odeprzeć. Po pierwsze, analizując temat tak szeroko obecny w sztuce, trzeba dokonać selekcji (zarówno 
bogactwo bibliografii, jak i inne teksty Chwina nie pozostawiają wątpliwości, że autor te opuszczone przypadki zna; pytanie tylko, czy jego decyzje się bronią). Po drugie zaś, argumentować można, że takie a nie inne zakreślenie tematyki („śledztwo" Chwina-badacza zlecone przez Chwina-człowieka) czyni owe eksplicytnie jedynie obecne samobójstwa (,,centralne metafory egzystencji") materiałem znacznie istotniejszym niż samobójstwa popełniane przez postaci z książek. Jeśli obie te sfery współistnieją - przypadek Biesów - to fantastycznie. Jeśli nie - skupmy się na tym pierwszym. Jest to z pewnością kwestia dyskusyjna. Być może owe wrażenie braku wywołane jest kontrastem z liczbą stron, jakie Chwin poświęca owym „okołosamobójczym czy „przedsamobójczym” fantazmatom.

Są jednak dwa teksty, o których obecność chciałbym się stanowczo upomnieć. Przede wszystkim dlatego, że samobójstwo nie jest jednym tylko z przedstawionych w nich zdarzeń, lecz ich podstawą i kluczem. Pierwszy z nich to Pętla Marka Hłaski (analiza tego opowiadania ukazać mogłaby płynność granicy między samobójstwem egzystencjalnym a "okolicznościowym”, wywołanym takimi czy innymi czynnikami, a co najmniej wskazała na możliwą zależność między nimi). Kolejnym zaś jest drugi rozdział Wściekłości $i$ wrzasku Wiliama Faulknera, czyli monolog Quentina Compsona toczony w dniu, w którym postanowił on utopić się w Charles River (istotny zarówno w kwestii stosunku samobójcy do czasu, jak i jako przypis dla rozdziału o samobójstwach w wodzie).

Druga teza obecna w Samobójstwie jako przygodzie wyobraźni odnajduje przyczynę pełnego paradoksów i ambiwalencji stosunku do samobójstwa w fakcie, że kultura naszkicowała dwie podstawowe, skrajnie przeciwstawne „ikony” („,iemną" i „jasną") wyznaczające etyczny - i poetyczny - charakter samobójczego gestu. Pierwszej z nich przyświeca Judasz, potępiony wszak nie za zdradę, lecz za samobójstwo właśnie, odstręczający, szkaradny, beznadziejnie przegrany na wieczność. Drugiej zaś takiej postaci, jak Lukrecja, Dydona, Kleopatra, czy Sokrates, Katon, Seneka (Petroniusz z Quo vadis jest również przykładem owej "jasnej" ikony), wreszcie wspomniany już Samson, których gest jest kulturowo waloryzowany pozytywnie jako dowód godności, prawości, męstwa (niestety, z braku lepszego, tym określeniem objąć muszę też wymienione powyżej kobiety), przykładnego i chwalebnego poświęcenia.

${ }^{6}$ Wspomnieć tu można, na zasadzie dygresji, o społecznych reakcjach na niedawne samobójstwo Andrzeja Leppera. Autorzy wielu komentarzy na portalach informacyjnych czy społecznościowych wykazywali wówczas niedowierzanie, zaskoczenie, szok, że „ktoś taki” (mowa tu o medialnym, niekorzystnym wizerunku polityka) był zdolny do "takiego" (kojarzonego z czymś „wyższym”) czynu. Z drugiej strony opis całej scenerii (łazienka, sznur od snopowiązałki, hak od worka bokserskiego przywodzący na myśl rzeźnię) oraz przyczyn (problemy, przede wszystkim finansowe) czynił ów gest w pewnym stopniu wstydliwym, by nie rzec haniebnym. 
Wychwytując kulturowe treści deponowane w tworzonych przez wieki przekazach wizualnych, Chwin błyskotliwie wskazuje, jak - dyskretnie, w dużej mierze "mimochodem" - konstruowane i podtrzymywane są dwie przeciwstawne narracje o samobójstwie: ta mroczna, brudna, piętnowana, i ta czysta, dostojna, bezkrwista i bezbolesna. Ta część „naukowej” partii książki - rekonstrukcja "polityki symbolicznej wobec samobójstwa” (s. 55) - robi największe wrażenie, co może dla Chwina, jako przede wszystkim badacza literatury, nie jest pochwałą do końca oczekiwaną. Analizy, które przeprowadza autor Esther, zestawić można z książką Mieke Bal Reading Rembrandt. Jej podtytuł doskonale oddaje efekt, który udało się Chwinowi osiągnąć - sytuuje się on beyond the word-image oposition. Ukazuje bowiem, w jaki sposób kulturowy stan świadomości, ów rezerwuar powszechnych poznawczych i normatywnych klasyfikacji, sprzężony jest z określoną obowiązującą (i podświadomie w procesie twórczym powielaną, bądź - kiedy wypracowana już jest gotowość przyjęcia określonego wiarołomstwa - przełamywaną) polityką przedstawiania. Lokuje to rozważania Chwina w ramach tzw. teorii kulturowych, analizujących, w jaki sposób dzieła sztuki odzwierciedlają warunki (kulturowy stan świadomości) ich wytwarzania.

Przeważająca część Samobójstwa jako przygody wyobraźni ma jednak charakter opisowy, panoramiczny, rekonstrukcyjno-interpretacyjny, wyznaczony trzema podstawowymi aspektami poprzedzającego samobójczy czyn „marzeniami” o nim. Po pierwsze, charakterem interakcyjnym (bądź skrajnie solipsystycznym) samobójstwa. Samobójca „mniej lub bardziej wyraźnie określa, do kogo adresuje swój czyn, daje sobie i innym znać »wobec « kogo, »dla« kogo, »za« kogo zamierza umrzeć, rysuje siatkę swoich sprzymierzeńców i prześladowców" (s. 44). Po drugie, egzystencjalnym sensem, jaki nadaje swojemu czynowi samobójca poprzez wybór odpowiedniej metody, uwzględniającej takie aspekty jak czas, przestrzeń, estetyka, stopień drastyczności itp. (z każdą opcją sprzężona jest bowiem odpowiednia fantazmatyczna przestrzeń). Po trzecie, tworzeniem „symbolicznego obrazu własnego ciała (...) w taki sposób, by zostało ono »otwarte« na przyjęcie śmierci" (s. 45), czyli - przede wszystkim - lokalizowaniem somatycznego "źródła życia”.

Rysując w wyobraźni „mapę” wewnętrzną swojego ciała, oznacza on [samobójca przyp. P.J.] na niej miejsca odczuwane jako szczególnie „śmiertelne”, gdzie - jak to odczuwa - kryje się sam nerw życia, miejsca neutralne, a więc takie, których ugodzenie nie gwarantuje śmierci, a także miejsca i sfery szczególnie wrażliwe na „niepotrzebne” urazy (s. 194-195).

Refleksja Chwina biegnie więc wielotorowo. Śledzi on wchodzące na scenę, wraz z romantycznym i modernistycznym odkryciem indywidualności, samobójstwo "nienarracyjne”, skrajnie osobiste i tajemnicze (jego emblematem jest w książce obraz Édouarda Maneta Samobójca z 1877 roku). Skrupu- 
latnie opisuje rozmaite formy odbierania sobie życia: $w$ ogniu, w wodzie (gęstej, ciemniej, albo łagodnej, przejrzystej), w powietrzu. Samobójstwa projektowane tak, by były ekstatyczne, momentalne (niczym orgazm lub atak epileptyczny), albo samobójstwa celebrowane, odgrywane z kontemplowaniem pełnej świadomości umierania. Samobójstwa "brudne” i „czyste”, delikatne i drastyczne, inwazyjne wobec materii ciała bądź nienaruszające jej itd. Następnie zaś - w rozdziałach Śmierć z własnej ręki i centralne metafory egzystencji oraz Jak wyobraźnia gromadzi argumenty przeciw życiu (nomen omen rozdzielenie tych części jest podyktowane chyba tylko i wyłącznie faktem, że jeden przytłaczający rozdział nie może zajmować połowy książki) - rekonstruuje założenia filozoficzne lub konstatacje egzystencjalne podbudowujące metaforyczne obrazy predysponujące do samobójstwa. Krytykę tej części przedstawiłem już wcześniej, przypomnę tylko, że jedynym analizowanym dziełem, które zawiera zarówno refleksję o samobójstwie, jak i przedstawia je jako element akcji, są Biesy Dostojewskiego. Fakt ten zaś studium Chwina przemilcza, licząc być może, że przedstawiany zbiór obroni się sam przez się, jeśli nie przez swoje bogactwo, to niewątpliwą rzetelność i godną pochwały wnikliwość w opisie poszczególnych eksponatów.

Nie sposób nie przedstawić Samobójstwa jako przygody wyobraźni jako lektury będącej dla czytelnika przygodą, imponującego popisu erudycji i pokazu interpretacyjnego close reading. Nie sposób jednak nie dostrzec również pewnych mankamentów tej książki. Właśnie książki - to pragnę podkreślić, gdyż poszczególne jej partie przeważnie bronią się w zakresie własnego celu i sposobu jego realizacji. Zestawienie ich jednak sprawia, że z trudem daje się dostrzec jednolity i przemyślany pomysł kompozycyjny całości. Czytając dzieło Chwina, nie mogłem się wyzbyć wrażenia pewnej niekoherencji, przypuszczeń, że to poszczególne rozdziały czy podrozdziały (odnoszę się tu wyłącznie do tej części, którą określiłem jako „naukową"), powstałe - być może - przy różnych (innych?) okazjach, zostały subsumowane pod jeden tytuł, jedną okładkę, nie zaś pomysł na całość wytyczył szlak ich pojawiania się i zestawienia. 